UDC 378.146:575

\title{
THE IMPORTANCE OF THE PRELIMINARY ASSESSMENT OF STUDENTS' KNOWLEDGE IN THE PROCESS OF TEACHING THE DISCIPLINE \\ "THE BASIS OF GENETICS"
}

\author{
AUTHOR'S DATA: \\ Spartak Palikyan, $\mathrm{PhD}$ in Biology, professor \\ Chair of Speech and Rehabilitative Therapy, ASPU. \\ Lecturer \\ Contacts: spartakpalikyan@icloud.com
}

\begin{abstract}
The article describes and considers the possibility of applying the results of preliminary testing of student's knowledge for increasing the effectiveness of teaching the courses within the frame of higher professional education, for which the school knowledge acts as basic. In this case the example of the course of "The Basics of Genetics" is discussed.
\end{abstract}

Key words: educational process, special education preliminary check, basis of genetics, preliminary knowledge, basic knowledge.

\section{INTRODUCTION}

The university's transition to the use of credit technology in the organization of the educational process, as well as the implementation of a new modular knowledge assessment system, create a fundamental need to objectively initialize learners' initial levels of knowledge in order to tailor their needs and abilities and from the very beginning to differentiate the approaches used while teaching process, determine the degree of complexity and intensity of the knowledge provided to each person in accordance with the basic knowledge of the course.

Knowledge testing in the higher education system is one of the most important components of the learning process, which significantly enhances the effectiveness of students' learning activities. The knowledge test or assessment enables to determine the volume, level, quality of the teaching material delivered, reveals the successes and disadvantages of the course study, on the basis of which appropriate adjustments are made, as well as the improvement of course content, teaching modes and methods is done (Amonashvili, 1984). 
The proper organization of the testing or assessment significantly affects the efficiency of the educational process and the quality of the training of professionals, creates favorable conditions for the development of learners' cognitive abilities, and activates their own self work (Aleksandrova, 2008).

Knowledge testing methods are the means of obtaining feedback on the content, nature and achievements of students' learning activities, as well as for evaluation of the overall effectiveness of the teacher's work [6]. They are intended to determine the quality of teaching in all stages of the teaching process. Very often, current, intermediate and final exams are used in the teaching process for knowledge evaluation, the basis of which is to identify the characteristics of didactic problems in different stages of learning. All these forms of testing and evaluation to some extent reflect the logic and objectives of the learning process (Smirnov, 2010; Krilova, 2013).

Preliminary testing, unlike the forms mentioned above, is rarely used in Armenia, although it is considered a prerequisite for further education process planning and management. Such testing enables the students to determine the level of initial knowledge (basic knowledge) and competence available to the learners, which will be considered as a basis for determining the level of complexity of the subsequent study material. As a rule, pre-testing has confirmatory (diagnostic) and diagnostic problems. It is taught at the beginning of each specific subject and aims to identify the level of knowledge, abilities, and skills of students at the beginning of the course. At the same time, the preliminary testing is also crucial in the initial phase of starting the process of learning. The information regarding the students' basic knowledge enables the teacher to determine the possible level of pedagogical influence on them and the possible outcomes of that influence. The pre-testing also allows the teacher to select the most effective forms and methods of work, as well as to tailor the course material and curriculum to the specificities of the student.

"The Basics of Genetics" as a training course is included in the basic cycle of general professional subjects of all specialties in the field of special education within the frame of state higher education standards of higher education. The uniqueness of this course within the structure of higher professional education is that for its effective study it is necessary for the student to have some background knowledge of general biomedicine and genetics. In the school education system, this level is provided in the framework of a general biology course. However, this subject is not elected by many students as a subject studied in high school, and not all constituents perceive it equally, and, at the same time, taking into account the fact that biology is no longer considered a 
competitive subject in the list of admissions exams in all recent education specialties (applicants are admitted to the university only after receiving a positive assessment of the Armenian language test), then it becomes clear that the biological knowledge of all of them is on different to the levels.

The aforementioned statement leads to the fact that, despite its complexities, genetics is becoming an increasingly difficult subject for first-year students. The prior knowledge of biology and genetics in the teaching of genetics has led to the fact that for some students the same study material may be very easy to master and for others quite difficult to study. Correspondingly, the results of the exams after the training are substantially different, as the same study knowledge is accumulated on different cognitive bases of the students. At the same time, in the context of university in-service training, the individual pedagogical approach to each student becomes very difficult and in many cases even almost impossible. That is why, in our opinion, the most logical way out in this situation is dividing students into the groups (streams) according to the prior level of knowledge gained from the field of genetics.

\section{STATEMENT AND ANALYSES OF THE SITUATION IN THE FIELD}

In the initial phase of studying the basics of genetics, the students' knowledge of general biology and genetics can be derived from a variety of sources:

1. School course of General Biology. Includes research in such areas as molecular genetics, classical genetics, fundamentals of genomics, and fundamentals of human genetics, evolutionary genetics, population genetics, and breeding grounds. The school curriculum creates a general conceptual environment for teaching the subject, giving general patterns and scientific achievements in the field of genetics.

2. General social informative environment. Gaining special knowledge in the field of genetics may be due to the widespread interest in modern society on issues such as human genetics, including sex genetics, breeding grounds, and medical genetics. Such everyday knowledge may be possessed by people who have experienced genetic abnormalities or diseases in their life experience, with a particular interest in the particular issues of this science related to paternity/maternity recognition, family tree building, and so on.

3. Special training courses or programs. Genetics is more widely studied in specialized pedagogical, medical, biological, and similar educational settings: colleges, vocational schools, and universities. In-depth study of genetics, genomics, and evolution in these 
educational programs within the frame of "school program" may include a variety of combinations, such as population and molecular genetics, genetic engineering, medical and sports genetics, environmental and physiological genetics, developmental genetics and so on.

Accordingly, the level of knowledge gained, as well as the degree of understanding the specificity of this or that topic, differs for all students studying genetics. By analyzing students' knowledge at the beginning of the course, the lecturer can arrange his/her work in a way as to produce more quality teaching results.

Based on the results of the pre-test organized at the beginning of the learning cycle, the lecturer can make adjustments to the thematic plan, decide to which sections of the curriculum should be given the most attention, and work out the ways to eliminate complications in students' knowledge. Thus, based on the results of the pre-test, it is possible for the students to be included in the groups with similar knowledge levels in order to select and differentiate the relevant program according to the learning rate. It means that teaching within a single student stream (group) becomes more personalized, which in turn will lead to deeper learning of the course material and further objective evaluation.

\section{AN ENTRY LEVEL KNOWLEDGE TEST DEVELOPMENT}

In our opinion, the most convenient and productive way of conducting a preliminary evaluation is using tests, as many authors consider it to be a very effective mean of assessment students' development style, knowledge, abilities and skills (Avanesov, 1994). The data obtained at the initial stage is subjected to statistical analysis and based on this, a qualitative description of the student's further progress from the course is given. Preliminary testing of knowledge can be carried out during the first courses of the training (baseline check), as well as at the beginning of the training of individual subjects (knowledge actualization). Incoming assessment testing is usually performed during the first lesson. In order to determine the initial level and specificity of knowledge on basics of genetics, an entry level knowledge test was developed by us and applied.

This test contains 40 questions accordingly with three levels of difficulty:

Level 1 comprises 10 relatively simple questions of general knowledge disclosure that will reflect the student's general knowledge of the subject.

For example, questions such as: 
1.1 Genetic information in the human body holds:

1) only sex cells,

2) all cells,

3) only non-sex cells,

4) brain cells.

1.2. Geneology is a research method of:

1) twins,

2) human genetic code,

3) families,

4) human evolution.

1.3. Human chromosome assembly consists of --- chromosomes:

1) 46 ,

2) 47 ,

3) 44 ,

4) 45 .

1.4. The combination of XY chromosomes conventionally means:

1) female sex,

2) male sex,

3) genetic disease,

4) mutation.

It is permissible that students may "guess" as a result of the "simpleness" of the questions. The successful passing of the "light" level of the test will contribute to the creation of successful situation and thereby will stimulate the students' motivation.

Level 2 comprises 15 questions of greater complexity and is designed to reveal the knowledge gained from general biology and chemistry courses.

For example:

2.1. RNA is:

1) ribonucleic acid,

2) deoxyribonucleic acid,

3) protein,

4) DNA breakdown compound. 
2.2. Homologous chromosomes are called:

1) sex chromosomes,

2) autosomes,

3) non-paired,

4) paired.

2.3. Recessively is:

1) the presence of only one allele in the heterozygous individual in the phenotypic manifestation,

2) the absence of phenotypic manifestation of the heterozygous individual,

3) the type of genetic pathology,

4) the over-expression of all species.

2.4. Point mutations associated with alterations in the nucleotide sequence of a DNA molecule within one gene are:

1) gene,

2) genomic,

3) chromosomal,

4) generative.

Level 3 contains 15 questions for discovering special knowledge in general and medical genetics. These questions are peculiarly scientific in their nature and reflect at a very simple level the topics of the further study sections of genetics as a subject.

These can be questions like:

3.1. The purpose of the twins divided from each other method is:

1) comparison of children in families where mothers and fathers are monozygotic twins,

2) evaluation of the intrinsic similarity of the traits studied in childhood separated twins,

3) targeted division of twins into different families for their further consideration,

4) evaluation of the intrinsic similarity of monozygotic twins separated from childhood.

3.2. Changing the scope of reading is:

1) the mutation that result in loss or incorporation of one or more nucleotides,

2) disruption of the translocation phase,

3) disruption of the transcription phase,

4) destruction of the process of cell fertilization. 
3.3. Scheme corresponding to the inversion of chromosome segment is:

1) B B WHERE^^ A B VGD;

2) $\mathrm{ABCGD}^{\wedge} \mathrm{ABCBWGD}$;

3) $\mathrm{ABWGDE} \wedge$ ABDGWE;

4) $\mathrm{CML} \mathrm{BUT}^{\wedge} \mathrm{ABUSE}$.

3.4. Which are sexually transmitted diseases?

1) Daltonism,

2) Down's Syndrome,

3) Patau's Syndrome,

4) Edwards Syndrome.

The principle of evaluating the success of a test is constructed by the following scheme shown on Table 1. Thus, the number of points given to the student can vary from 1 to 85 .

Table 1.

Assessment of test success on the entry level knowledge test for the subject "The basis of Genetics"

\begin{tabular}{|l|l|l|}
\hline Level of test & $\begin{array}{l}\text { Correct answer rating and } \\
\text { maximum grade rating }\end{array}$ & Qualitative rating \\
\hline 1 (10 questions) & 1 point, maximum: 10 points & level of domestic knowledge \\
\hline 2 (15 questions) & 2 points, maximum: 30 points & level of school knowledge \\
\hline 3 (15 questions) & 3 points, maximum: 45 points & Level of special knowledge \\
\hline
\end{tabular}

By doing most of the first and second level assignments correctly, the student will show quite encouraging results both in terms of predetermined and future tasks. Students who have less than 10 points in Level 1 and Level 2 tests will either be offered a repeat course in general biology and genetics, or will be assigned additional independent work in accumulation to teaching the basics of genetics. Students performing Level 1 and Level 2, as well as Level 3 assignments partly, will demonstrate high results that will demonstrate their specific knowledge of genetics.

In the event of further progress in further studies, these students may be exempt from the study of particular subjects, focusing more on other parts of the course. 
Based on the results of the entrance tests, the students are divided into 3 groups:

1st group, students with 1-20 points,

2nd group, students with 20-40 points,

3rd group, students with 40-85 points.

The research shows that only up to $5 \%$ of first-year students reach 60 points, with the majority of students show the results in the range of 20 to 40 points (Figure 1).

Figure 1. Statistical Distribution of 1st year students of ASPU Faculty of Special and Inclusive Education according to the scores from the entrance test of the subject "Genetics Basics".

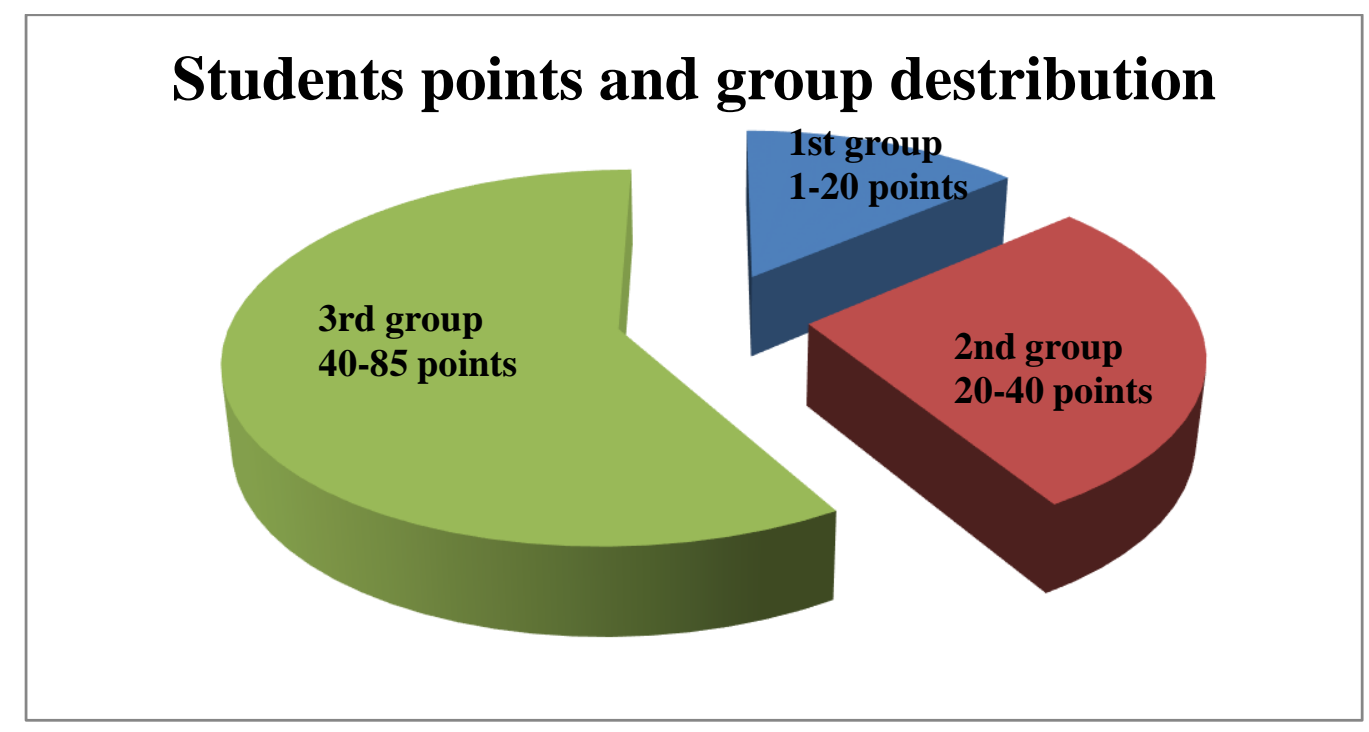

Of course, the pre-test method does not yet reveal the full depth and completeness of the knowledge, abilities and skills. But its main significance is not there. Based on the data obtained, the lecturer can plan the repetition and organize the study of the new material.

The variety of pedagogical forms of lectures, methodic as well as the form of organization of practical placements enables them to be delivered on the same topic, with varying degrees of complexity in the delivery of the material, or with different styles of active and interactive teaching methods (Slavgorodskaya, 2013).

A level-headed approach to the teaching process is also effective in organizing students' own classroom activities, as well as and extracurricular work organized out of classroom (Ozherelyeva, 2013). 
In this sense, as useful pedagogical approach can be used the pre-selection of individual, thematic tests and assignments, as well as the choice of different complexity options for the whole course.

\section{CONCLUSION}

Thus, we divide the students into groups based on the results of the pre-test organized both during the practical (seminar) classes and while evaluation of the intermediate test assignments and final exam results. In conclusion it should be noted that according to educational didactic principles (Gulidov, 2005; Lobashev, 2006) the pre-testing process must comply with the requirements of objectivity (introducing uniform requirements to all students, fair assessment of everyone's knowledge), with an individualized and differentiated approach to knowledge assessment that will enable the lecturer too fully and adequately identify the student's knowledge.

We believe that just passing the entrance test on course of "The basics of Genetics" can help the teacher in determining an objective assessment of the student's individual level of knowledge. This form of pre-testing also allows the teacher to analyze the individual dynamics of the student's level of knowledge, thereby implementing sufficient pedagogical approach in determining the final grade.

This method of knowledge pre-testing can be used not only in the teaching of Genetics. It can be widely used in the teaching of many subjects within the frame of higher professional education, for which the school knowledge acts as basic. For example, these courses can be: "Human Anatomy and Physiology", "Neurophysiology", "Neuropathology" and so on.

\section{REFERENCE LIST}

1. Aleksandrova, M. A. (2008) Pedagopgicheskiy control v processe vospitaniya: metodicheskiye rekomendacii (Pedagogical control in the process of education: methodological guidelines), M. A. Aleksandrova, N.A. Alekseeva, E. N. Stepanova, M. Sfera, $160 \mathrm{~s}$.

2. Amonashvili, Sh. A. (1984) Vospitatelnaya I obrazovatelnaya funkcii ocenki obucheniya: Eksperementalnoe pedagogicheskoe issledovanie (Educational functions of learning assessment: Experimental pedagogical research), Sh. A. Amonashvili M.: Pedagogika, 296 s. 
3. Avanesov, V. S. (1994) Nauchniye problem testogogo kontrolya znaniy (Scientific problems of test knowledge control) / V. S. Avanesov, M.: Issledovatelskiy centr problem kachestva podgotovki specialistov, $135 \mathrm{~s}$.

4. Gulidov, I. N. (2005) Pedagogicheskiy control i ego obespecheniye (Pedagogical control and its support) / I.N. Gulidov. M.: Forum. 2005. 240 s.

5. Krilova, M. N. (2013) Sposobi motivacii uchebnoy deyatelnosti studentow vuza (Methods of motivating the educational activities of university students) II Perspektivy nauki i obrazovaniya, №3. s. 86-95.

6. Lobashev, V. D. (2006) Socialno-psikhologocheskie aspekti kontrolya znaniy (Sociopsychological aspects of knowledge control) II Obrazovanie v sovremennoy shkole, №3, s. 30-39.

7. Ozherelyeva, T. A. (2013) Razvitiye metodov testirovaniya (Development of testing methods) II Perspektivy nauki i obrazovaniya, №6. s. 20-25.

8. Slavgorodskaya, E. L. (2013) Aktivniye sredstva organizacii uchebno-professionalnoy deyatelnosti studentov (Active means of organizing educational and professional activities of students) II Perspektivy nauki i obrazovaniya, №3. s. 96-105.

9. Smirnov, S. D. (2010) Pedagogika I psikhologiya visshego obrazovaniya: ot deyatelnosti $\mathrm{k}$ lichnosti (Pedagogy and psychology of higher education: from performance to individuum) / S. D. Smirnov. - M.: Izdatelskiy centr "Akademiya”, 400 s. 